\title{
Nutrition and enteric diseases in calves
}

\section{By J. H. B. Roy and J. H. Ternouth*, National Institute for Research in Dairying, Shinfield, Reading $R G 2{ }_{9} A T$}

Enteric diseases are of considerable economic importance in calves (a) during the first 2-3 weeks of life, when Escherichia coli is the main organism involved; (b) in the slightly older pre-ruminant calf and also in the young ruminant calf when salmonellosis, particularly that associated with Salmonella dublin and S. typhimurium, may cause severe losses;

(c) in the ruminant calf at pasture when a sufficiently heavy burden of internal parasites may cause clinical disease.

The discussion in this paper will be limited to enteric disease during the early neonatal period, many aspects of which have been discussed at a recent conference in the USA (Tennant, 197I). The manifestation of this disease is considered to depend on the interactions of the immunological, nutritional and microbiological environments of the calf, with its genotypic resistance.

\section{The microbiological environment}

In the normal healthy calf, $E$. coli is one of the first organisms to become established in the alimentary tract after birth, followed by the lactobacilli which become the commonest organism in the stomach and small intestine (Smith, I965). The temporary dominance of the first organisms to colonize the tract has been attributed to the high $\mathrm{pH}$ of the abomasal contents in the neonate and the subsequent decline of these organisms has been associated with the increased secretion of abomasal acid.

A strain of $E$. coli is only likely to be pathogenic either if it manages to enter the tissues during the first few days of life, resulting in a septicaemia, or if the strain, although restricted to the alimentary tract, has the ability to proliferate in the anterior region of the small intestine and to produce an enterotoxin. $\Lambda$ n $E$. coli septicaemia is usually associated with deprivation of colostrum or with the feeding of inadequate amounts, although a virulent serotype such as $078: \mathrm{K}$ (?) $\mathrm{B}$ will regularly cause a septicaemia in calves given colostrum.

The proliferation of an enteropathogenic strain of $E$. coli, which as long ago as I925 was shown by Smith \& Orcutt (I925) to adhere to the epithelial cells of the mucosa, results in profuse diarrhoea, dehydration and death from an $E$. coli localized intestinal infection associated with a metabolic acidosis.

*Present address: Department of Animal Husbandry, University of Queensland, St Lucia, Queensland 4067, Australia. 
The production of profuse diarrhoea and the passage of water and particularly the electrolytes $\mathrm{HCO}_{3}^{-}, \mathrm{Na}^{+}, \mathrm{Cl}^{-}$into the lumen of the intestine as a result of the proliferation of enterotoxaemic strains have been demonstrated by Smith \& Halls (I967) and Bywater (1970). It has also been shown that the 'enterotoxaemic' factor (Ent) can be transmitted from one strain of $E$. coli to another. The selection advantage possessed by enteropathogenic $E$. coli organisms probably resides in their ability to proliferate in the anterior small intestine (Smith \& Halls, 1968). One factor that certainly predisposes to the change from non-pathogenic to enterotoxaemic strains of coli is the passage of a large number of newborn susceptible animals through a confined air-space (Roy, Palmer, Shillam, Ingram \& Wood, 1955; Wood, 1955). A similar association between enterotoxaemic strains of $E$. coli and the physical environment is shown in infantile diarrhoea, since the majority of outbreaks occur in hospital wards or nurseries (Anonymous, 1970).

\section{The immunological environment}

The mode of transmission of passive immunity to the calf from its dam by way of colostrum is universally agreed. It can be seen from Table I that serum and most body secretions contain immune globulins (Ig), and that IgA is produced by all the normal secretory organs. Large quantities of $\mathrm{IgG}$, mainly in the form of $\mathrm{IgG}_{1}$, are present in colostrum; the relatively high content of IgM has been associated with antibodies against Gram-negative bacteria, such as E. coli (Michael \& Rosen, I963). Both IgG and IgM are selectively transferred to colostrum from the blood (Porter, 1971). The IgA in colostrum is presumed to be synthesized in the udder tissue. It has been shown in the pig that IgA contains antibodies to $E$. coli (Porter, 1969). Although IgA has a localized action in the intestinal tract in the human, and a deficiency may allow multiplication of bacteria in the duodenum (Hersh, Floch, Binder, Conn, Prizont \& Spiro, 1970; Prizont, Hersh \& Floch, 1970),

Table I. Immune globulins $(I g)$ in bovine external secretions and serum (Mach \& Pahud, 1971)

\begin{tabular}{|c|c|c|c|c|}
\hline & \multicolumn{4}{|c|}{ Protein concentration $(\mathrm{mg} / 100 \mathrm{ml})$} \\
\hline & $\begin{array}{c}\text { IgA } \\
\text { (secretory Ig) }\end{array}$ & $\operatorname{IgG}_{1}$ & $\operatorname{IgG}_{2}$ & $\operatorname{Ig} M$ \\
\hline Lachrymal secretions & 260 & 30 & 12 & 0.6 \\
\hline Nasal secretions & 195 & 4 & $2 \cdot 5$ & $\operatorname{Tr}_{\mathbf{r}}$ \\
\hline Saliva & $5^{6}$ & 3 & $\mathrm{I}$ & $\mathrm{I}$ \\
\hline Spermatic fluid & 13 & $\mathrm{r} 3$ & II & $\operatorname{Tr}$ \\
\hline Gastro-intestinal secretions & 24 & 25 & 6 & $\mathrm{Tr}$ \\
\hline Bile & 8 & ro & 9 & 5 \\
\hline Urine & 0.07 & 0.08 & $0 . I$ & $\operatorname{Tr}$ \\
\hline Colostrum & 440 & 7500 & 190 & 490 \\
\hline Milk & 5 & 35 & 6 & 4 \\
\hline Serum & 30 & 1050 & 790 & 250 \\
\hline
\end{tabular}


the role of IgA in the alimentary tract of the young calf has not yet been established; the concentration in cow's milk is, however, considerably lower than that in the milk of the sow (Porter, 1971).

Quite small amounts of colostral $\mathrm{Ig}\left(\mathrm{I}_{4} \mathrm{~g}\right.$ ) will offer good protection against an $E$. coli septicaemia, provided that the Ig contains antibodies against the antigens of the strains of coli to which the calves have been exposed (Aschaffenburg, Bartlett, Kon, Roy, Sears, Thompson, Ingram, Lovell \& Wood, 1953). More recently, Logan \& Penhale (I97r) have obtained $95 \%$ protection against an E. coli septicaemia with an intraperitoneal injection of $0.26 \mathrm{~g} \mathrm{IgM}$ and $\mathrm{I} \cdot 5 \mathrm{~g} \mathrm{IgG}$ as colostral whey $/ 30 \mathrm{~kg}$ live weight; either Ig given alone was ineffective.

These small quantities of colostrum, however, will not protect against the enterotoxaemic form of the disease in which the $E$. coli does not invade further than the mesenteric lymph-nodes. The amount of Ig necessary to protect against this condition is not known. Kruse (1970a) has suggested that roo $\mathrm{g}$ Ig should be given in the first feed to ensure a normal serum Ig concentration. Since $3 \cdot 4 \mathrm{~kg}$ colostrum, containing about $200 \mathrm{~g} \mathrm{Ig}$, followed by a diet of whole milk does not prevent the depression in growth rate that occurs when successive calves are introduced into a calf-house (Roy et al. 1955), it would appear that in an adverse microbiological environment, considerably greater amounts of Ig may be necessary. To ensure complete protection under these conditions one would recommend giving at least $7 \mathrm{~kg}$ colostrum collected during the first $24 \mathrm{~h}$ after parturition. This quantity would supply about $400 \mathrm{~g}$ Ig during the first $24-36 \mathrm{~h}$ of life.

Weijers \& van de Kamer (1965) have suggested that, in the human, the harmful effects of $E$. coli in the small intestine and colon, as a result of amine and toxin production, will depend on the amount of antibodies and the activity of the amine oxidase in the cell walls of the colon. Although in the severely diarrhoeic piglet the small intestine is the principal site of amine production compared with the colon in unaffected animals (Hill, Kenworthy \& Porter, 1970), no experiments have so far directly implicated production of amine as a factor in the aetiology of an E. coli localized intestinal infection in the calf. However, increased amounts of amines, particularly histamine and putrescine, have been obtained from strains isolated from calves that died compared to those from healthy calves (Ferenciik, Koppel \& Križánova, 1970).

\section{The nutritional environment}

The association of putrefactive diarrhoea in man with the dominance of $E$. coli and with inefficient digestion of protein and of fermentative diarrhoea with inefficient carbohydrate utilization has been reviewed by Weijers \& van de Kamer (1965). The relevance of these findings to diarrhoea in calves has been discussed by Roy (1969).

In the normal healthy young calf, clotting of the casein with the entrapped fat occurs within 3-4 min of ingestion of milk. Complete passage of the whey fluid, which contains the lactose, the whey proteins including the small amount of Ig that is present and much of the minerals, requires about $7^{-9} \mathrm{~h}$ (Mylrea, I966; Hill, 
Noakes \& Lowe, I970; Ternouth, 1971). The casein retained in the abomasum is partly degraded into peptides as a result of the action of rennin or pepsin, or both, and $\mathrm{HCl}$, and together with the fat is passed continuously through the pylorus for further degradation by the pancreatic enzymes. In calves being fed ad lib. twice daily, the slow passage of casein out of the abomasum, presumably necessary to allow sufficient time for effective abomasal proteolysis to occur, results in the clot that is formed after a meal entrapping some of the clot formed from a previous meal (Hill, Noakes \& Lowe, I970; Ternouth, I971). Some neonatal calves appear to produce mainly rennin whereas others produce only pepsin, but pepsin production predominates as the calf gets older (Henschel, Hill \& Porter, 196r).

Milk substitutes for calves generally contain at least $50 \%$ of skim-milk powder. When milk is heat-treated in the production of milk powders and the time-temperature relationship is such that the majority of the whey proteins, including the small amount of Ig present are denatured, normal clotting of the reconstituted milk powder does not occur and instead of a firm curd, a flocculent precipitate may be produced in vitro (Roy, 1969). Milk substitutes containing such powders have a reduced digestibility, particularly of protein and also of fat and ash. Such diets will predispose the calf to death from an $E$. coli localized intestinal infection in an adverse microbiological environment. Gastric digestion is reduced and undigested casein passes into the duodenum. Abomasal fluids pass more slowly through the pylorus and have a higher $\mathrm{pH}$, which appears to be associated with the production of less acid (Tagari \& Roy, 1969; Ternouth, 1971). Poor gastric digestion is not complemented by an increased output of pancreatic proteolytic enzymes. Indeed, the effect of feeding a 'severely' heat-treated milk is also to reduce the secretion of pancreatic fluids and proteases (Table 2). Associated with the reduction in the output of proteases, is an increase in the secretion of amylase from the pancreas (Ternouth, 1971).

Heat denaturation of the small amount of Ig and of other inhibitory factors, such as lactoperoxidase, in milk may also encourage certain enteropathogenic organisms. For instance, Singh \& Mikolajcik (1971) have shown in in vitro studies that the heat treatment of skim milk has a marked stimulatory effect on the growth of $S$. typhi-murium.

Experiments with milk substitute containing $40 \%$ or more of the protein as soya have indicated a similar train of events to that arising from a diet containing a 'severely' heat-treated milk, namely a reduced rate of abomasal outflow, a higher $\mathrm{pH}$, a reduction in proteolysis in the abomasum and an escape of undigested protein into the duodenum (Colvin, Lowe \& Ramsey, 1969; Ternouth, 1971), together with less pancreatic secretion and a lower protease outflow (Gorrill \& Thomas, 1967; Gorrill, Thomas, Stewart \& Morrill, 1967; Ternouth, 1971).

Poor clotting of milk, as a result of heat treatment, has also been reported to have an immunological effect (Frens, van der Grift \& Dammers, I96r; Frens, 1961). Absorption in the small intestine of only partially broken-down milk proteins may occur, with the resultant formation of antibodies in the blood, so that at a later stage anaphylactic shock symptoms may be observed. This observation has not been 
Table 2. Comparison of a milk substitute diet containing 'mildly' and 'severely' preheated spray-dried skim-milk powder

$\begin{array}{cccc}\text { 'Mild' } & \begin{array}{c} \\ \text { 'Severe' } \\ \text { pre-heating } \\ \text { pre-heating } \\ \text { treatment }\end{array} & & \\ \left(77^{\circ} \mathrm{C} \text { for }\right. & \left(74^{\circ} \mathrm{C} \text { for }\right. & \text { Change } & \\ 15 \mathrm{~s}) & 30 \mathrm{~min}-\mathrm{t}) & (\%) & \text { Reference }\end{array}$

Incidence of mortality during first $2 \mathrm{I} d$ of life $(\%)$

\begin{tabular}{|c|c|c|c|}
\hline 24 & 53 & +125 & $\begin{array}{l}\text { Shillam, Roy \& } \\
\text { Ingram (196z) }\end{array}$ \\
\hline $\begin{array}{l}I \\
0.20\end{array}$ & $\begin{array}{l}3 \\
0.09\end{array}$ & $\begin{array}{l}+ \\
-55\end{array}$ & $\begin{array}{l}\text { Shillam \& Roy } \\
(1963 b)\end{array}$ \\
\hline 14 & 12 & $-\mathbf{I}$ & Shillam \& Roy \\
\hline 25 & 37 & +48 & $(1963 a)$ \\
\hline $3^{8}$ & 55 & +45 & 'Tagari \& Roy (1969) \\
\hline $2 \cdot 54$ & $2 \cdot 30$ & -10 & \\
\hline 105 & 124 & $+\quad 18$ & \\
\hline 41 & 39 & -5 & . \\
\hline 53 & $(84) \dagger$ & +58 & \\
\hline & & & Ternouth (1971) \\
\hline 0.015 & 0.004 & -73 & \\
\hline 52 & 43 & -17 & \\
\hline 239 & 210 & -12 & \\
\hline 336 & 300 & - II & \\
\hline $\begin{array}{l}2 \cdot 30 \\
37\end{array}$ & $\begin{array}{l}x \cdot 67 \\
5 x\end{array}$ & $\begin{array}{r}27 \\
+\quad 38\end{array}$ & \\
\hline
\end{tabular}

No. of days in which calves had diarrhoea during first $2 \mathrm{I} d$ of life

Live-weight gain $/ \mathrm{d}$ in first $2 \mathrm{I} d$ of life $(\mathrm{kg})$

Dry-matter content of faeces at $7 \mathrm{~d}(\%)$

Indigestibility of protein at $7 \mathrm{~d}(\%)$

Abomasal outflow:

Protein $\mathrm{N}$ as $\%$ of total $\mathrm{N}$ during first $6.5 \mathrm{~h}$ after a feed

Duodenal flow :*

Volume of fluid during first $3 \mathrm{~h}$ after a feed (1)

Protein concentration during first $3 \mathrm{~h}$ after a feed (mg/roo ml)

Protein $\mathrm{N}$ as $\%$ of total $\mathrm{N}$ during I2 $\mathrm{h}$ after a feed

Recovery of ${ }^{3} \mathrm{H}$ from casein during $12 \mathrm{~h}$ after a feed $(\%)$

Estimated gastric acid production from duodenal flow:

Ionized $\mathrm{H}^{+}$in first $3 \mathrm{~h}$ after a feed $(\mathrm{mmol} / \mathrm{h})$

$\mathrm{Cl}^{-}$less $\mathrm{Na}^{+}$in excess of intake during first $3 \mathrm{~h}$ after a feed (mmol) $12 \mathrm{~h}$ after a feed (mmol)

Pancreatic secretion:

Volume ( $\mathrm{ml} / \mathrm{/2} \mathrm{h})$

Protease activity $(\mathrm{g} / \mathrm{I} 2 \mathrm{~h})$

Amylase activity (mg//2 h)

37

$(\%)$

Reference

* At the site $\mathrm{r} 50 \mathrm{~mm}$ caudal to the pylorus.

†Whole milk heated to $80-85^{\circ}$ for $30 \mathrm{~min}$.

confirmed by others (Boogaerdt \& van Koetsveld, 196r), but it has been shown (van Adrichem \& Frens, I965; van Leeuwen, Weide \& Braas, 1969) and more recently confirmed (Smith \& Wynn, 197I) that antibodies against soya protein may be produced in the blood as a result of giving this protein. Moreover, it has been suggested that there is an association between the production of antibodies and gastric stasis, followed by diarrhoea, which can by induced when soya is the sole source of protein (Smith, Hill \& Sissons, r970).

Liquid skim-milk is also known to cause a greater incidence of diarrhoea than whole milk and it has been assumed (Roy, 1969) that the higher protein content of skim milk was responsible. However, Ternouth (197I) has found that abomasal proteolysis is greater when skim milk is given (Table 3 ). This suggests that the diarrhoea may be of the fermentative rather than the putrefactive type, due to 
Table 3. Comparison of a milk substitute diet containing $20 \%$ fat with a diet of liquid skim-milk

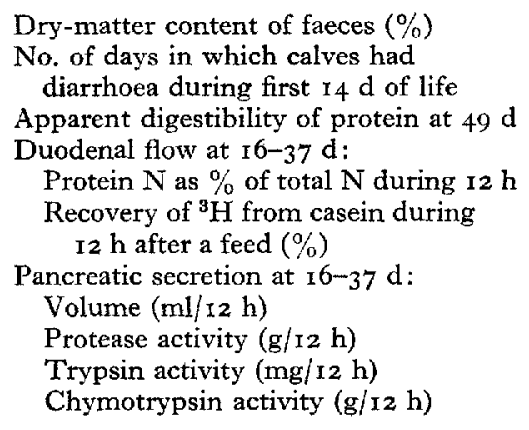

\begin{tabular}{|c|c|c|c|}
\hline $\begin{array}{l}20 \% \text { fat } \\
\text { milk }\end{array}$ & $\begin{array}{l}\text { Skim } \\
\text { milk }\end{array}$ & $\begin{array}{c}\text { Change } \\
(\%)\end{array}$ & Reference \\
\hline I4 & ro & -28 & Roy, Stobo \& \\
\hline 0.1 & $i \cdot 3$ & + & Gaston (1970) \\
\hline 94 & 94 & 0 & \\
\hline 46 & 36 & -22 & \\
\hline 53 & 45 & -15 & Ternouth $(\mathbf{1 9 7} \mathbf{1})$ \\
\hline $\begin{array}{l}305 \\
6 \cdot 5\end{array}$ & $\begin{array}{l}276 \\
5 \cdot 3\end{array}$ & $\begin{array}{l}-10 \\
-18\end{array}$ & \\
\hline 295 & 233 & $-2 \mathrm{I}$ & \\
\hline $1 \cdot 29$ & 1.02 & $-2 \mathrm{I}$ & $\begin{array}{l}\text { J. H. Ternouth } \\
\text { (unpublished) }\end{array}$ \\
\hline
\end{tabular}

excessive concentration of lactose in the diet. However, since the pancreatic secretion of proteases, trypsin and chymotrypsin are also reduced as a result of giving skim milk, a finding that may be related to the absence of a stimulatory effect by fat, the possibility of putrefactive diarrhoea cannot be ruled out.

Feeding techniques, which have on occasions been reported as a cause of diarrhoea or of a reduced growth rate, all tend to cause a reduction in gastric acid production, the degree of abomasal proteolysis or pancreatic protease production, or both (Ternouth, 197I). For instance, bucket-feeding versus teat-feeding (Wise \& LaMaster, 1968), once-daily feeding versus twice-daily feeding (Wood, Bayley \& MacLeod, I971) and cold milk versus warm milk (Walker, r950) have been associated with an increased incidence of diarrhoea and also cause alterations in the digestive processes.

\section{The genetic environment}

The lower susceptibility of Friesian compared with Jersey and Ayrshire calves to diarrhoea under the same nutritional and microbiological conditions, and its possible relationship with the higher apparent digestibility of protein by the Friesian breed have been discussed by Roy (1969, I970). It would thus seem to be more than a coincidence that Friesian calves appear to have a greater secretion of trypsin and protease from the pancreas than do Ayrshire calves of the same age (Table 4) (Ternouth, $197 \mathrm{I}$ ). As with the effect of a 'severely' heat-treated milk, the lower rate of protease secretion in the Ayrshire calves is associated with a higher rate of amylase secretion.

The Black and White Danish Breed (SDM) is also claimed to absorb Ig more efficiently than the Red Danish (Kruse, I970b), the Friesian $\hat{\sigma} \times$ Ayrshire $q$ calves to absorb Ig better than Ayrshire calves (Selman, McEwan \& Fisher, $197 \mathrm{r} b$ ). Moreover, beef calves of various crosses have been shown to suckle their dams 
earlier ( $8 \mathrm{I}$ min from birth) than pure bred Ayrshire or Friesian $\hat{o} \times$ Ayrshire + calves out of heifers $(218 \mathrm{~min})$ or cows $(26 \mathrm{I} \mathrm{min}$ ) (Selman, McEwan \& Fisher, I $970 a, b)$.

Table 4. Comparison at the same age of calves of the Friesian and Ayrshire breeds given milk diets

\begin{tabular}{|c|c|c|c|c|}
\hline & Friesian & Ayrshire & $\begin{array}{l}\text { Change } \\
(\%)\end{array}$ & Reference \\
\hline Dry-matter content of faeces at $32 \mathrm{~d}(\%)$ & 16 & 12 & -25 & \\
\hline $\begin{array}{l}\text { Apparent indigestibility of protein at } \\
32 \mathrm{~d}(\%)\end{array}$ & $4 \cdot 9$ & $9 \cdot 2$ & +88 & \\
\hline Metabolic faecal $\mathrm{N}$ at $32 \mathrm{~d}(\mathrm{~g} / \mathrm{I} 00 \mathrm{~g}$ dry- & 0.12 & 0.40 & -308 & $\begin{array}{l}\text { Roy, Stobo \& } \\
\text { Gaston }(1970)\end{array}$ \\
\hline $\begin{array}{l}\text { No. of days in which calves had diarrhoea } \\
\text { during first } \mathrm{I}_{4} \mathrm{~d} \text { of life }\end{array}$ & $0 \cdot 1$ & $\mathbf{I} \cdot \mathbf{2}$ & + & \\
\hline $\begin{array}{l}\text { Serum concentration of absorbed } \mathrm{Ig}- \\
48 \mathrm{~h} \text { after birth (zinc sulphate } \\
\text { turbidity units) }\end{array}$ & $14 \cdot 9^{*}$ & II.O & -26 & $\begin{array}{l}\text { Selman, McEwan \& } \\
\text { Fisher }(197 \mathrm{r} b)\end{array}$ \\
\hline $\begin{array}{l}\text { Secreted pancreatic protease activity at } \\
24 \mathrm{~d}(\mathrm{~g} / \mathrm{I} 2 \mathrm{~h}) \dagger\end{array}$ & $6 \cdot 0$ & $2 \cdot 8$ & -53 & Ternouth, Siddons \\
\hline $\begin{array}{l}\text { Secreted pancreatic trypsin activity at } \\
24 \mathrm{~d}\left(\mathrm{mg} / \mathrm{I}_{2} \mathrm{~h}\right) \dagger\end{array}$ & 257 & 176 & & \& Toothill (197I) \\
\hline
\end{tabular}

The psychological environment

In man, fear may result in gastric function being delayed and food remaining undigested in the stomach for many hours. In baby piglets, diminishing gastric activity followed by gastric stasis had been shown to occur before the onset of diarrhoea (White, Wenham, Sharman, Jones, Rattray \& McDonald, 1969). Gastric stasis may well arise in calves as a result of the stress of transport and could be partly associated with the high incidence of enteric infection in purchased calves. The importance of the psychological environment has recently been further emphasized by the finding that calves given colostrum by hand, but left in the presence of their dams, absorb more Ig from colostrum than calves given the same amount of colostrum but reared in isolation; possibly this 'mothering' effect is related to grooming by the dam (Selman, McEwan, \& Fisher I97 $1 a, b$ ).

\section{Conclusion}

Enteric disease of the newborn calf is basically a result of alterations in gastric and intestinal function in response to a less than optimum diet, but the severity of the condition and its clinical manifestation as an infectious disease will depend on the age of the calf and the balance between the immunological and microbiological environment of the calf. 
Anonymous (1970). Br. med. J. ii, 58 .

Aschaffenburg, R., Bartlett, S., Kon, S. K., Roy, J. H. B., Sears, H. J., Thompson, S. Y., Ingram, P. L., Lovell, R. \& Wood, P. C. (I953). Br. F. Nutr. 7, 275.

Boogaerdt, J. \& van Koetsveld, E. E. (1961). Tijdschr. Diergeneesh. 86, I287.

Bywater, R. J. (1970). \%. comp. Path. 80, 565 .

Colvin, B. A., Lowe, R. A. \& Ramsey, H. A. (r969). J. Dairy Sci. 52, 687.

Ferenčik, M., Koppel, Z. \& Križánova, H. (1970). Vet. Cas. 12, 137.

Frens, A. M. (1961). Tijdschr. Diergeneesk. 86, 1636.

Frens, A. M., van der Grift, J. \& Dammers, J. (1961). Tijdschr. Diergeneesk. 86, 255.

Gorrill, A. D. L. \& Thomas, J. W. (1967). $尹$. Nutr. 92, 2 1 5.

Gorrill, A. D. L., Thomas, J. W., Stewart, W. E. \& Morrill, J. L. (1967). F. Nutr. 92, 86.

Henschel, M. J., Hill, W. B. \& Porter, J. W. G. (I96r). Proc, Nutr. Soc. 20, xl.

Hersh, T., Floch, M. H., Binder, H. J., Conn, H. O., Prizont, R. \& Spiro, H. MI. (I970). Am. Y. clin. Nutr. 23, 1595 .

Hill, I. R., Kenworthy, R. \& Porter, P. (1970). Res. vet. Sci. rr, 320.

Hill, K. J., Noakes, D. E. \& Lowe, R. A. (1970). In Physiology of Digestion and Metabolism in the Ruminant, p. i66 [A. T. Phillipson, editor]. Newcastle upon Tyne: Oriel Press.

Kruse, V. (1970a). Anim. Prod. r2, 6rg.

Kruse, V. (1970b). Anim. Prod. 12, 627.

Logan, E. F. \& Penhale, W. J. (1971). Vet. Rec. 88, 222.

Mach, J-P. \& Pahud, J.-J. (197 I). Y. Immun. I06, 552.

Michael, J. G. \& Rosen, F. S. (r963). F. exp. Med. I18, 6ro.

Mylrea, P. J. (1966), Res, vet. Sci. 7, 394.

Porter, P. (1969). Immunology 17, 617.

Porter, P. (r97I). Biochim. biophys. Acta 236, 664.

Prizont, R., Hersh, T. \& Floch, M. H. (1970). Am. \%. clin. Nutr. 23, 1602.

Roy, J. H. B. (1969). Proc. Nutr. Soc. 28, 160.

Roy, J. H. B. (1970), F. Sci. Fd Agric. 21, 346.

Roy, J. H. B., Palmer, J., Shillam, K. W. G., Ingram, P. L. \& Wood, P. C. (1955). Br. F. Nutr. 9, Ir.

Roy, J. H. B., Stobo, I. J. F. \& Gaston, H. J. (1970). Br. J. Nutr. 24, 459.

Selman, I. E., McEwan, A. D. \& Fisher, E. W. (r970a). Br. vet. F. 126, 495.

Selman, I. E., McEwan, A. D. \& Fisher, E. W. (1970b). F. comp. Path. 80, 419.

Selman, I. E., McEwan, A. D. \& Fisher, E. W. (1971a). Res. vet. Sci. 12, X.

Selman, I. E., McEwan, A. D. \& Fisher, E. W. (1971b). Res. vet. Sci. 12, 205.

Shillam, K. W. G. \& Roy, J. H. B. (1963a). Br. F. Nutr. x7, г7 I.

Shillam, K. W. G. \& Roy, J. H. B. $(1963 b)$. Br. Y. Nutr. 17, 183.

Shillam, K. W. G., Roy, J. H. B. \& Ingram, P. L. (1962). Br. F. Nutr. 16, 585.

Singh, V. K. \& Mikolajcik, E. M. (1971). F. Milk Fd Technol. 34, 205.

Smith, H. W. (1965). F. Path. Bact. 90, 495.

Smith, H. W. \& Halls, S. (1967). F. Path. Bact. 93, 499.

Smith, H. W. \& Halls, S. (1968). \%. gen. Microbiol. 52, 319.

Smith, R. H., Hill, W. B. \& Sissons, J. W. (1970). Proc. Nutr. Soc. 29, 6A.

Smith, R. H. \& Wynn, C. F. (1971). Proc. Nutr. Soc. 30, 75A.

Smith, T. \& Orcutt, M. L. ((925). F. exp. Med. 4r, 89.

Tagari, H. \& Roy, J. H. B. (I969). Br. F. Nutr. 23, 763 .

Tennant, B. (197I). Ann. N.Y. Acad. Sci. r76.

Ternouth, J. H. (I97I). Studics of the role of the abomasum and pancreas in digestion in the young calf. PhD Thesis, University of Reading.

Ternouth, J. H., Siddons, R. C. \& Toothill, J. (1971). Proc. Nutr. Soc. 3r, 89 A.

van Adrichem, P. W. M. \& Frens, A. M. (1965). Tijdschr. Diergeneesk. 90, 525.

van Leeuwen, V. M., Weide, H. J. \& Braas, C. C. (1969). Versl. landbouzw. Onderz. Ned. no. 732.

Walket, D. M. (I950). Bull. Anim. Behav. 8, 5.

Weijers, H. A. \& van de Kamer. J. H. (1965). Nutr. Abstr. Rev. 35, 591.

White, F., Wenham, G., Sharman, G. A. M., Jones, A. S., Rattray, E. A. S. \& McDonald, I. (1969). Br. F. Nutr. 23, 847 .

Wise, G. H. \& LaMaster, J. P. (I968). F. Dairy Sci. 5I, 452.

Wood, A. S., Bayley, H. S. \& MacLeod, G. K. (I97I). F. Dairy Sci. 54, 405.

Wood, P. C. (I955). F. Path. Bact. 7o, 179. 